\title{
FOXES IN THE HENHOUSE: LEGAL CRITIQUE TO THE “JUS BELLUM JUSTUM" DOCTRINE FOR HUMANITARIAN INTERVENTION THROUGH THE RESPONSIBILITY TO PROTECT
}

\section{RAPOSAS NO GALINHEIRO: CRÍTICA JURÍDICA À DOUTRINA DO “JUS BELLUM JUSTUM” PARA INTERVENÇÃO HUMANITÁRIA ATRAVÉS DA RESPONSABILIDADE DE PROTEGER}

\section{HENRIQUE JERÔNIMO BEZERRA MARCOS}

Researcher and Doctoral Student in Foundations and Methods of Law at the University of Maastricht (UM) Graduate School of Law. Doctoral Student in International and Comparative Law at the Faculty of Law of the University of São Paulo (USP). Master of Legal Sciences (M.Sc.) at the Federal University of Paraíba (UFPB). Teacher of Scientific Research Methods at "Mentoria de Pesquisa em Direito". Researcher at the Center for Studies in International Courts (Núcleo de Estudos em Tribunais Internacionais, NETI-USP) of the University of São Paulo (USP). ORCID: https://orcid.org/0000-0003-0259-5530. E-mail: henriquejbmarcos@gmail.com

\section{GUSTAVO RABAY GUERRA}

Ph.D. in Law, State and Constitution at the University of Brasília. Master in Public Law (M.Sc.) at the Federal University of Pernambuco (UFPE). Professor of Law at the Federal University of Paraíba (UFPB) and University of João Pessoa (UNIPÊ). Member of the Law School Program of Postgraduate of Law and Development at UNIPÊ. Partner at Rabay, Palitot e Cunha Lima Law Firm. ORCID: https://orcid.org/0000-0003-3040-3313. E-mail: rabay@me.com 


\begin{abstract}
Objective: The paper presents a legal analysis of R2P in light of contemporary international law. It questions whether R2P is lawful as a just war (jus bellum justum) doctrine under international law, specifically under the general prohibition for the use of force pursuant to the Charter of the United Nations. The paper first analyzes the just war doctrine in light of international law; thereafter, there is a study of the legal framework for the use of force in the United Nations Charter; and, in a third step, the study of the R2P in legal light as a just war doctrine.
\end{abstract}

Methodology: The research is executed through a deductive approach, its scientific objective is exploratory, and its research technique is a bibliographical and documentary survey. The methodological limit is in a legal approach of the subject from a normative perspective, focused on the legal validity of the institute under international law.

Results: It is concluded from the study that R2P has legal flaws and does not stand against United Nations Charter regulation on the usage of force, notably the norm that states that the use of force in international relations is an exclusive responsibility of the United Nations Security Council.

Contributions: The study shows its pertinence as an endeavor into a strictly legal analysis of a complex and highly political subject of humanitarian interventions.

Keywords: Responsibility to protect; humanitarian intervention; just war doctrine; United Nations Security Council.

\title{
RESUMO
}

Objetivo: $O$ artigo apresenta uma análise jurídica da R2P à luz do Direito Internacional contemporâneo; questiona se a R2P é juridicamente válida como uma doutrina de guerra justa (jus bellum justum) sob o Direito Internacional, especificamente à luz da proibição geral de uso da força de acordo com a Carta das Nações Unidas. Para tanto, o artigo analisa a doutrina da guerra justa à luz do Direito Internacional; em seguida, estuda o marco legal para o uso da força na Carta da ONU; e, em terceiro lugar, estuda a R2P como uma doutrina de guerra justa.

Metodologia: A pesquisa é executada através de abordagem dedutiva, seu objetivo científico é exploratório e sua técnica de pesquisa é bibliográfica e documental. $\mathrm{O}$ limite metodologia é uma abordagem legal do seu objeto em uma perspectiva normativa com foco na validade legal do instituto à luz do Direito Internacional. 
Resultados: Conclui-se do estudo que a R2P tem falhas jurídicas e não se coaduna com a normativa da Carta das Nações Unidas sobre o uso da força, notadamente a norma que estabelece que o uso da força nas relações internacionais é uma responsabilidade quase exclusiva do Conselho de Segurança das Nações Unidas.

Contribuições: $O$ estudo mostra sua pertinência por se tratar de análise estritamente legal de um assunto complexo e altamente político que são as intervenções humanitárias.

Palavras-chave: Responsabilidade de proteger; intervenção humanitária; doutrina da guerra justa; Conselho de Segurança das Nações Unidas.

\section{INTRODUCTION}

This paper aims to study the contemporary "just war" (jus bellum justum) doctrine of humanitarian intervention: Responsibility to Protect (R2P). It questions whether R2P is lawful (i.e., legally valid) as a just war doctrine under international law, specifically under the general prohibition for the use of force pursuant to the Charter of the United Nations (UN). That is the main research question (research problem). The preliminary hypothesis is that - despite some political and ideological argumentation - from a legal standpoint, R2P is defective, given that it contradicts the Charter's legal framework for the use of force. Thus, the main objective is to present a legal analysis of R2P in light of international law. As intermediary objectives, it intends to: (i) consider broad just war doctrine in the light of contemporary international law; (ii) analyze the legal framework for the use of force in the UN Charter; and (iii) study R2P as a just war doctrine. Regarding the methodology chosen, the research is executed through a deductive approach, its scientific objective is exploratory, and its research technique is a bibliographical and documentary survey.

It is paramount to observe that this research finds its methodological limits in a legal approach of the subject from a normative perspective focused on the legal validity of the institute under international law. Therefore, in this paper, the scientific interest is purely legal, and, likewise, so are the conclusions. It is a juristic - not a 
political - approach to the problems at hand. The paper deals with the law in effect over the institutes it considers, not with its actual or desired role in the international play of powers. ${ }^{1}$ Nonetheless, the study at hand shows its pertinence as an endeavor into a strictly legal analysis of a complex and highly political subject: humanitarian interventions. ${ }^{2}$ In this sense, the research attempts to shed legal light into a matter which holds high relevance to the international protection of human rights. ${ }^{3}$ Furthermore, other than the Middle East (which is a constant subject of these military actions), there are currently active discussions in the Permanent Council of the Organization of American States (OAS) concerning the "need" for intervention in Latin-America over the crisis in Venezuela under the 1947 Inter-American Treaty of Reciprocal Assistance (Tratado Interamericano de Asistencia Recíproca, TIAR or "Tratado de Río") (OAS, 2019b).

\section{THE FORMULA FOR THE JUST WAR DOCTRINE}

There is no arguing against the mainstream conviction that war is a terrible ordeal. This perception is confirmed by the early writings of both Horace ${ }^{4}$ and Herodotus, ${ }^{5}$ who warned their listeners and future generations of the perils caused by war. Nevertheless, waring is a perennial condition of humankind, and conflicts can be considered a natural progression of relations between different groups of individuals, ranging from small tribes to modern states. In order to adjust to this paradoxical situation - the horror of war and its inexorable condition - there have been many efforts to justify the use of force. That is, even if it is a terrible decision, according to

\footnotetext{
${ }^{1}$ On the legal interpretation of international law, see (KELSEN, 1951).

${ }^{2}$ On a postcolonial critique of R2P, see (MAHDAVI, 2015).

${ }^{3}$ For the purposes herein, human rights are understood as the sum of civil, politic, economic, social, cultural, and collective rights stipulated by international and regional instruments and international customary law (PETERKE, 2009, p. 86-87).

4 "Many delight in the camp, in the sound of the trumpet mingled with the clarion, and in the wars that mothers hate." (HORACE, 1995, p. 5).

5 "No man is so foolish as to desire war more than peace: for in peace sons bury their fathers, but in war fathers bury their sons". (HERODOTUS, 1975, p. 113).
} 
those who defend it, it is not always the worst option to go to war. The reasons held vary dramatically along the millennia, but the efforts of argumentation are still constant.

An illustrative case of mythical arguments of both divinity and Natural Law are the ones brought forward in the "lliad" through its contemplation on the honor of

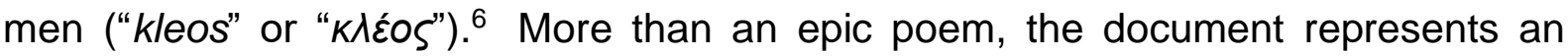
amalgamation of a cultural perspective that has profound implications into the understanding of Law and morality for that particular society. In this sense, the arguments raised by the characters can be a source for understanding a vision into what that war represented and whether if that conflict was justified (ROISMAN, 2008, p. 100). Even if the arguments have a mythical and (probably) fictitious origin, they are still a fruitful source for us to draft a theoretical definition for the formula of the just war doctrine. Considering, on the one hand, a hypothetical situation where legal rights or assets protected by law are subject to violation or risk of an imminent breach, and, on the other hand, the intrinsic terribleness of war, is the conflict justifiable? If the rights or assets outweigh the risks and foreseeable losses of war, there is a casus belli, i.e., there is a situation that justifies war (it is a "just war"). If not, then no, that war is not just and, in a legal system which adopts the doctrine, the declaration of war would be a priori unlawful.

Throughout legal history, the formula evolved, changing what rights and assets were relevant enough to justify the conflict: honor, divine will, land claims, human rights. However, the same pragmatic formula persists within the just war doctrine. For instance, weighting war against the native populations of the Americas, citing Saint Thomas Aquinas, Francisco de Vitoria concludes that the denial of the Christian faith was not enough of a cause to justify conflict between the European

\footnotetext{
6 "Mother tells me, the immortal goddess Thetis with her glistening feet, that two fates bear me on to the day of death. If I hold out here and I lay siege to Troy, my journey home is gone, but my glory never dies. If I voyage back to the fatherland I love, my pride, my glory dies... true, but the life that's left me will be long, the stroke of death will not come on me quickly." (HOMER, 1991, p. 265). "[...] the men whom Zeus decrees, from youth to old age, must wind down our brutal wars to the bitter end until we drop and die, down to the last man." (HOMER, 1991, p. 372).
} 
princes and the Amerindians (VITORIA, 2010, p. 270-271). Hence, similar to the discussion in the lliad as to whether the Greeks were justified for going to war against the Trojans, in Vitoria, the formula remains similar. The substantial difference is the legally protected right (or asset) in the two cases: Honor in the former, salvation through the Christian faith in the latter. In Hugo Grotius the evolution continues through his attempt to remove ideological considerations as justification for a just war, systematizing what he believes are the just causes for war. War is justified when for defense, for the recovery of one's property or one's debt, or for the punishment of an offense committed (GROTIUS, 2005, p. 393). However, even then, the formula above remains true.

\section{JUST WAR DOCTRINE IN CONTEMPORARY INTERNATIONAL LAW}

Within the "Peace of Westphalia" non-intervention paradigm, there is subsequent difficulty in recognizing a concept of just war in line with what was stated above (GROSS, 1948). That is not to say that there were no more conflicts. However, considering the equal status of states, they were no longer in clear a position to judge whether another state's cause was just or not (SHAW, 2017, p. 853). Historical progression reaches the Covenant of the League of Nations and the Kellogg-Briand Pact. The Covenant of the League of Nations did not prohibit war entirely. It created a set of procedural and temporary rules that had to be followed by the memberstates, but it allowed war if it was necessary for the maintenance of right and justice (Articles 12 and 15 of the League Covenant). The Kellogg-Briand Pact, on its turn, prohibited war as an instrument of national policy (Article 1). Among others, Hans Kelsen interprets that the Pact - a contrario sensu - does not prohibit war as an instrument of international policy, i.e., the use of force is not forbidden as a means of international politics and, above all, that it is not a reaction against the violation of international law, nor as an instrument to maintain and realize international law (KELSEN, 1996, p. 62). 
Nevertheless, the substantial unfolding of the rules for defining just war can be felt through the signature of the UN Charter, where the peaceful settlement of disputes was universally recognized as a peremptory principle to be observed by the states in their international relations. Article 2.4 of the Charter is definite. In their international relations, all member-states shall refrain from the threat or use of force against the territorial integrity or political independence of any state. Also, Article 2.6 of the Charter goes as far as ruling that even states which are not members of the UN must act per the UN rules on the use of force to maintain international peace and security. Moreover, in the Charter, the word "war" is not present in any of its Articles (KELSEN, 1952, p. 29), appearing only once its Preamble while it refers to the scourges caused by the two World Wars.

Legally, the Charter replaces "war" with "use of force". As a broader concept, the use of force encompasses what is understood as war. As defined by Kelsen (1952, p. 32), war is a coercive action between states. Bilateral (attack and counterattack) or unilateral (without reaction), and in line with the Westphalian paradigm: War is an affair of states. ${ }^{7}$ The use of force, on the other hand, makes no such subjective requirements. Any individual or collective can be responsible for the use of force, be it a state, an international organization, an organ of such - e.g., the United Nations Security Council (UNSC) - or even a terrorist group (MARCOS, 2018, p. $57)$.

Going even further than its predecessors, the UN Charter obligates the member-states not only not to resort to the use of force but to refrain from the threat of the use of force, legally binding them to settle their disputes by peaceful means. The only legal exceptions for this general prohibition on the use of force are the "enforcement actions" divided into three categories. (i) Use of force as a reaction of the UN itself, through the UNSC's Chapter VII powers, in the face of a threat to the peace, breach of the peace, or act of aggression (Article 39). (ii) As an extraordinary

\footnotetext{
${ }^{7}$ Contemporary scholars argue that it is theoretically possible to recognize the existence of "war" between a State and non-State entities such as urban insurgencies and criminal organizations in a Humanitarian Law perspective (PETERKE, 2010).
} 
and provisional measure of self-defense that must be immediately informed to the UNSC so it can exercise its authority (Article 51). (iii) Moreover, as a historical remnant, the UN Charter permits action against an enemy state of the Second World War (Article 107). The usage of force is reserved to the UNSC, the only authority in contemporary international law which can use force in a definite and lawful manner against members-states as well as non-members (KELSEN, 1948, 785). Even selfdefense - which, at first, could be considered an exception to the UNSC's monopoly - is, as mentioned, implemented on a provisional basis. According to the UN Charter, force can only be used in the case of "immediate" self-defense, i.e., instantaneous, proportional, and temporary, in an attempt to contain the aggression previously suffered. Also, the states must immediately notify the UNSC of the action so the Council may decide by itself what are the future appropriate measures (SORTO, 2005, p. 149). In this sense, scholars refer to the conclusion reached by the International Court of Justice in the "Democratic Republic of Congo v. Uganda Case" (ICJ, 2005, p. 222). There is no clause considering the gravity of the situation or its complexity as a possible exception. Regardless of the dimension of the international conundrum, in the Charter, there are no legal grounds for the use of force other than the exceptions placed above (MENEZES, 2013, p. 111). It can even be said that the prohibition on the use of force is a peremptory norm of the jus cogens status (LINDERFALK, 2016, p. 52-53; ICJ, 1986, p. 90-91).

In this sense, considering the general prohibition of its usage in international relations, the case for a just war doctrine in the light of the UN Charter is left on a second level. Nonetheless, Kelsen presents an argument in favor of a just war doctrine within the Charter. However, the depiction presented by the author is considerably objective. It has no elements considering the gravity of the violation of the legal right or asset as the classic formula given above. In Kelsen's view, the jus bellum justum doctrine is expressed as follows: 
sanction if it is not to be considered a delict. This is the doctrine of bellum justum, just war. If the doctrine of bellum justum is correct, then under general international law the employment of force on the part of one state against another is in principle forbidden as a delict; but it is exceptionally allowed as a reaction against a delict, that is to say, as a sanction (KELSEN, 1951, p. 707).

According to Kelsen, it is possible to interpret the enforcement action case for the use of force as a reaction of the UN itself (through the UNSC's Chapter VII powers) as a sanction applied by the organization against the unlawful state responsible for the threat to the peace, breach of the peace, or act of aggression. In this case, in Kelsen's view, the UN Charter adopts a form of just war doctrine (KELSEN, 1951, p. 708). Nonetheless, his just war doctrine has less margin for ponderation. It is a simplified binary formula (ZOLO, 1998, p. 312). If the use of force (or war) is in accordance with the legal grounds authorized by the UN Charter (notably the use of force by collective action through Chapter VII powers), it is a just war. Outside of the realm of legal categories, it is unlawful. Moreover, in this last case, the illegal war is in itself a case that authorizes the use of force by collective action. Whether one accepts or disapproves of Kelsen's attempt to re-propose the just war doctrine, it seems intuitive that, under contemporary international law, the lawful use of force is one that meets the requisites presented by the UN Charter. If it falls outside of that threshold, it is unlawful, i.e., in disagreement with the legal rules in effect.

\section{HUMANITARIAN INTERVENTION THROUGH R2P}

Humanitarian intervention can be understood when a state (or a collective of states) decides to militarily interfere in the realm of another state's sovereignty in order to, allegedly, protect the rights of persons situated within this latter state from a violation (GRANT; BARKER, 2004, p. 268). It is a political concept that outdates human rights as a legal institute. For one, Oppenheim refers to the intervention perpetrated by Britain. France, and Russia in 1827 in the struggle between 
revolutionary Greece and Turkey, given the public opinion surrounding the cruelties committed during the struggle (OPPENHEIM, 1912, p. 426). Some scholars argue that humanitarian interventions draw its appeal from the revolutionary discourse of human rights and the - conjectural - idea that humanitarian intervention is an instrument capable of enacting emancipatory ideals, freedom from oppression, and fundamental respect for human dignity (ORFORD, 2003, p. 34). On the other hand, it is possible to argue that humanitarian intervention is an oxymoron that serves as a pretext for selective military interventions with uncertain results (BADESCU, 2011, p. 2).

From a contemporary legal standpoint, arguments in favor of humanitarian intervention through the use of force must stand in accordance with the UN Charter. Especially the norms presented above that state the legal grounds for the use of force. In this sense, humanitarian interventions are permissible if they are following the UN Charter. Thus, a priori, humanitarian interventions are a matter that should be decided by the UN through the UNSC Chapter VII powers. However, following the premise of the monopoly of the UNSC on the use of force, and the failures of the international community to adequately respond to the crisis in Rwanda and Bosnia in the 1990s, former Secretary-General of the UN Kofi Annan questioned this paradigm:

\begin{abstract}
Some critics were concerned that the concept of "humanitarian intervention" could become a cover for gratuitous interference in the internal affairs of sovereign states. [...] But to the critics I would pose this question: if humanitarian intervention is, indeed, an unacceptable assault on sovereignty, how should we respond to a Rwanda, to a Srebrenica - to gross and systematic violations of human rights that offend every precept of our common humanity? We confront a real dilemma. Few would disagree that both the defence of humanity and the defence of sovereignty are principles that must be supported. Alas, that does not tell us which principle should prevail when they are in conflict. (ANNAN, 2000, p. 48)
\end{abstract}

To examine the matter, the Canadian Government funded the International Commission on Intervention and State Sovereignty (ICISS), which published a report on their newly established institute, the "Responsibility to Protect", a reinterpretation of state sovereignty to state responsibility (ICISS, 2001b). This is the core principle 
of R2P. It comprehends state sovereignty as a responsibility, proposing that the core responsibility of states for the protection of its people lies within the state of which territory those individuals are (state obligations inherent in the concept of territorial sovereignty). However, there is a secondary responsibility that arises when some state fails to fulfill its primary responsibility. Where a population is subject to human rights violations arising from war, insurgency, repression or general state failure and the state is unable or unwilling to act, the rule of non-intervention yields to the secondary responsibility to protect which the whole international community is subject (ICISS, 2001a, p. 5-12).

Nonetheless, R2P is arguably a broader concept than just military humanitarian intervention. It presents a framework that includes preventive nonmilitary action as one of its most important dimensions (EVANS, 2008, p. 56). The Responsibility to Protect is divided into three categorical "responsibilities". (i) The Responsibility to Prevent: the obligation to address the root and direct causes for future internal conflicts and crises that could place populations at risk (ICISS, 2001b, p. 19). (ii) The Responsibility to React: the obligation to respond to situations of compelling humanitarian need with appropriate measures, including sanctions, international prosecution, and military intervention. (ICISS, 2001b, p. 29). (iii) The Responsibility to Rebuild: the obligation to provide, after the intervention, assistance for recovery, reconstruction, and reconciliation (ICISS, 2001b, p. 39). Thus, it is possible to argue that R2P proposes a new regulation for humanitarian intervention (i.e., humanitarian intervention through responsibility to protect). Nonetheless, the institute does not limit itself on jus ad bellum.

Considering proper humanitarian intervention through R2P, the document proposed by the ICISS presents a "just cause threshold". It states that military intervention for the protection of human rights is an exceptional and extraordinary measure. To be warranted, there must be a concrete or imminent case of grave violation against human rights in at least one of the two kinds. (a) Large scale loss of life, with or without genocidal intent, a product of deliberate state action, neglect, or inability. (b) Large scale "ethnic cleansing", whether actual or apprehended, through 
killings, forced expulsion, acts of terror, or sexual aggression (ICISS, 2001b, p. 32). Furthermore, the document presents precautionary principles for the use of force. These principles include analysis of the "right intention", i.e., that the primary purpose for the intervention must be to halt or avert human suffering, which (according to the ICISS) is better assured through multilateral operations supported by regional opinion and the participation of victims. Additionally, humanitarian intervention is only justified as a last resort, and when its scale, duration, and intensity is the minimum necessary to secure its objectives. Finally, the document states that, for the humanitarian intervention to be warranted, there must be a reasonable chance of success through military means, i.e., that there is a sufficient correlation between the means and the end intended (ICISS, 2001b, p. 35).

An interesting aspect to be considered is when the document refers to what would be the "right authority" for the lawful deflagration of the usage of force in international relations. Firstly, the ICISS recognizes that the primary and appropriate authority to decide on the use of force is the UNSC. The document states that its original intent is not to find alternatives to the Security Council as a source of authority but to contribute to ensuring the effectiveness of the UNSC procedure. The document emphasizes that Security Council authorization should be sought before any action being carried out. On the other hand, it underlines that the UNSC should deal promptly with the requests on intervention (ICISS, 2001b, p. 49). Likewise, it proposes that the permanent members of the Security Council should commit to refrain on applying their Article 27 veto powers in matters related to military humanitarian intervention. However, in the event where the UNSC rejects a proposal or fails to deal with the issue in a time considered reasonable, the document presents two alternative options. (a) Take the matter to be decided by the United Nations General Assembly (UNGA) under the "Uniting for Peace" procedure (ICISS, 2001b, p. 48). (b) Action within regional or sub-regional international organizations pursuant to Article 52, Chapter VIII of the UN Charter, subject to ex post facto authorization from the UNSC (ICISS, 2001b, p. 54). Finally, the ICISS document presents a set of operational principles, including specific rules concerning rules of engagement, 
coordination with humanitarian organizations, a joint military approach with a unity of command, and a clear and unambiguous mandate with clear objectives (ICISS, 2001b, p. 57).

Regarding the "Uniting for Peace" alternative, the procedure was first established through UNGA Resolution 377 (UNGA, 1950) as an attempt to grant the General Assembly secondary responsibility for maintaining international peace through an interpretation of the UN Charter. According to Resolution 377, if the UNSC fails to exercise its primary responsibility to maintain international peace and security, the UNGA is authorized to recommend to member-states collective measures including the use of armed force (KELSEN, 1951, p. 147). Although the "Uniting for Peace" procedure has been used a few times throughout recent practice (notably in the case of Namibia's independence in 1981), a significant number of states are reluctant to consider actions taken based on this Resolution as legal (WEISS, 2005, p. 30-31).

In 2005, a re-proposed "Responsibility to Protect" was presented through the "World Summit Outcome Document" enshrined in UNGA Resolution 60 of 2005. This edition of the Responsibility to Protect, however, is far less creative than the one presented by the ICISS. The document urges the international community to take action to prevent a humanitarian crisis, mentioning that there is a general responsibility to prevent and deal with such situations. However, it presents no alternatives to the use of force. It recognizes that collective action through the use of force is to be done through the UNSC pursuant to Chapter VII of the UN Charter (UNGA, 2005). Considering the focus of this particular research, the World Summit Responsibility to Protect poses no evident legal complexities. It is a general humanitarian plea directed to the global community, and its content appears to be in accordance with Charter law. 


\section{LEGAL COMPLEXITIES ON THE USE OF FORCE THROUGH R2P}

Having analyzed the regulation of the use of force in contemporary international law through the UN Charter, and having presented the structural aspects surrounding the proposed legal usage of force through R2P as proposed by the ICISS, this paper will now refer to some aspects of R2P that can raise complexities and potential contradictions with the law in effect. Foremost, it seems that, at this time, an adequate interpretation is one that understands R2P as "soft law". ${ }^{8}$ Its aspiration to become international law is, at most, emerging (DORR, 2008, p. 207). Even for those who are favorable to its adoption, it is strenuous to admit that it is a norm of customary international law, especially considering the resistance and critiques over its usage. There is a lack of opinio juris sive necessitatis and state practice (HEHIR; MURRAY, 2013, p. 92-93).

Moreover, as a preliminary standard for a legal interpretation of R2P, it is necessary to consider the status of the UN Charter in contemporary international law. Due to the provision of Article 103, the Charter holds a position of primacy and precedence over general international law. Following the International Court of Justice's "Nicaragua" precedent, this was the understanding of the Court of Justice of the European Union in the "Kadi v. Commission Case" of 2005, where it decided that Charter law prevails over the other norms of international law (COURT OF JUSTICE OF THE EUROPEAN UNION, 2005, p. 3713). Similarly, in the 1993 "Bosnia Case" of the International Court of Justice, Judge Lauterpacht's separate opinion observed that the UN Charter - and, as a result, the UNSC's Resolutions - hold a special status in international law, second only to jus cogens norms. In the justice's view,

\footnotetext{
8 "Soft Law. A term used to refer to non-binding instruments or documents which have the appearance of law. 'This is a body of standards, commitments, joint statements or declarations of policy or intention (think, for instance of the Helsinki Final Act of 1975), resolutions adopted by the UN GA or other multilateral bodies, etc. Normally "soft law" is created within international organizations or is at any rate promoted by them. It clearly relates to human rights, international economic relations or the protection of the environment' [...]. So, while not legally binding, soft law can be politically influential in setting down objectives and aspirations which may crystallize into custom or be adopted as treaties. [...]" (GRANT; BARKER, 2009, p. 558).
} 
only in the event of a violation of jus cogens was it possible to overcome a UNSC Resolution acted out according to the UN Charter (ICJ, 1993, p. 440). Hence, the UN Charter has a "supremacy clause" that stipulates that the obligations under Charter law shall prevail in the event of a conflict over commitments under other international agreements (LIIVOJA, 2008). This conclusion is relevant for the analysis because for R2P to be considered a valid legal norm in international law, it must be under the UN Charter. The Charter creates a minimum normative standard that not only regulates but establishes an insurmountable legal framework for any permissible governmental activity (TOMUSCHAT, 1992, p. 44). However, it appears that the ICISS's R2P proposal presents some deviancy from the UN Charter's legal frame.

\subsection{THE JUST CAUSE THRESHOLD}

A first complexity concerns RP2's "just cause threshold". It seems that, alongside its precautionary principles, the just causes are an adaptation of the original just war formula. Similar to the historical cases presented, R2P proposes two kinds of (human) rights violations that (theoretically) justify a declaration of war. However, according to the evolution of the jus bellum justum doctrine already examined above, it is possible to conclude that in contemporary international law (especially in UN Charter law) there is no legislative gap on the usage of force. If a contemporary just war formula is conceivable, it is, as presented by Kelsen, binary (legal or illegal). In the light of international law, a just war can be comprehended as a hypothesis of the usage of force in following the legal cases set in the UN Charter. As a deduction, any usage of force disaccording with the three valid categories of enforcement action outlined in the Charter is legally invalid. Even if there are strong moral and humanitarian arguments in favor of action, there is no legal clause in the UN Charter considering the gravity of the situation or its complexity as a possible exception.

An argument that could be raised by the supporters of R2P is that humanitarian intervention is lawfully justified as self-defense. If there is a case for 
self-defense and simultaneous humanitarian help, at first, the argument seems admissible. Consider a frontier conflict with genocidal action and border invasions by the guilty state; the innocent state could lawfully exercise its right of self-defense to prevent further aggression, and its activity would concurrently provide humanitarian aid. Withal, it is relevant to observe the legal limits surrounding pre-emptive selfdefense. Even if the subject matter is far from settled, the "Caroline Case" remains critical to understand the legal restrictions surrounding self-defense against imminent aggression accurately. As expressed by the US Secretary of State in 1837, the preemptive self-defense is lawful when it is exercised by a state which is facing immediate and overwhelming necessity, leaving no choice of means and no moment for deliberation (RAYMOND, 2007, p. 100-101).

In any case, as mentioned, according to Article 51 of the UN Charter, selfdefense is implemented on a provisional basis. It can only be used in the case of "immediate" self-defense, i.e., instantaneous, proportional, and temporary. Furthermore, it must be immediately reported to the UNSC so it can exercise its primary and perennial responsibility to maintain international peace and security. Hence, it appears that there is no legal basis for ongoing humanitarian intervention based on self-defense. A similar critique can be made against R2P's precautionary principles. Even if the principles seem persuasive and reasonable, its considerations fall outside the legal framework of the UN Charter. ICISS's states that military intervention is justified as a last resort. From a legal viewpoint, even if it is such (the last resort), there is no legal basis for the usage of force (unless it is one of the cases set forward in the Charter) and, thus, it is unlawful.

\subsection{AUTHORITY FOR THE USE OF FORCE: UNGA'S “UNITING FOR PEACE” AND REGIONAL ORGANIZATIONS}

Another aspect of R2P to be considered are its considerations over the right authority for the use of force. The UN Charter is clear: The UNSC is the organ responsible for decisions concerning the use of force in international relations. In this 
sense, the "Uniting for Peace" UNGA procedure is legally problematic. It can be argued that the Resolution falls outside the catalog of UNGA functions set on Chapter IV of the UN Charter. Strictly, the Charter allows UNGA to consider matters and to recommend measures under certain conditions, but not to resolve that it shall. In other words, according to the UN Charter, the UNGA is not authorized to confer upon itself peremptory or definite powers for deciding matters (KELSEN, 1951, p. 959-960). Hence, if UNGA were to recommend to member-states to adopt military measures, it would be doing so outside the scope of its competence and in an act without binding effects. Thus, if a state (or states) were to act following UNGA, they would be doing so by their own will and in conflict with international law. In this respect, as mentioned, the prohibition on the use of force and the UNSC's monopoly over its usage is a peremptory norm of the jus cogens status. In sum, the "Uniting for Peace" procedures are in weak legal grounds (JOHNSON, 2014, p. 115). A suitable interpretation of the Charter and UNGA's responsibility for international peace and security would be one that states that if UNGA believes that on a question under its consideration, the use of force is necessary, it must refer this matter to the UNSC (KELSEN, 1951, p. 962).

A similar critique can be made against the second alternative offered by the ICISS document, i.e., action within regional or sub-regional international organizations. The UN Charter does not preclude the validity of regional arrangements provided that they are consistent with the Charter itself (given the supremacy rule under Article 103 mentioned above). Article 52 of the Charter permits these regional organizations to act in the functions of peaceful settlement of local disputes. Likewise, regional organizations may act as organs of the UN in taking enforcement action under the authority of the UNSC. However, without preceding UNSC authorization, enforcement actions under the regional arrangements are only permissible in three cases. (i) The general rule of enforcement action in the exercise of collective self-defense. (ii) Enforcement action as a measure against enemy states of the Second World War. (iii) Usage of force provided for in regional arrangements 
directed against a renewal of aggressive policy on the part of an enemy state. (See Articles 53 and 54 of the UN Charter.)

The third case is deserving of a detailed analysis. It authorizes regional agencies and states under regional arrangements to resort to force against ex-enemy states to combat the renewal of an aggressive policy. Thus, enforcement action is permissible. There is, however, a temporal restriction: "[...] until such time as the Organization may, on request of the Governments concerned [...]". This passage means that the states concerned have the right to maintain the status quo for as long as they please (or, at least, as long as the UNSC determines that the situation at hand is a threat or a breach of international peace or security). However, this norm is specifically tailored towards ex-enemy states, i.e., the members of the UN are not obliged by the Charter to refrain from the threat or use of force against ex-enemy states (KELSEN, 1951, p. 809-813). Therefore, the Charter does not create an exception for "future enemy states". In this sense, there is an explicit limitation for an attempt to interpret it in a way that allows the use of force with motivations that are not to prevent the renewal of an aggressive policy by an ex-enemy state. Any attempt to do so would fall outside of the UN Charter framework and, analogous to the explained above, become unlawful.

Moreover, the claim favorable to an ex post facto authorization through the UNSC ignores a fundamental aspect of the legality on the use of force according to the UN Charter. Firstly because (other than the self-defense case) collective enforcement action is done through the UNSC, i.e., it is the Security Council that acts (even if through states). Secondly, this interpretation ignores the Charter's gradual procedure under Articles 40, 41, and 42, which presents the UNSC with a series of legal instruments to be used preliminarily to the use of force. Furthermore, an interpretation that considers the ex post facto authorization valid is one that admits the risk of a system of continuous and subsequent retaliation. It is similar to what Kelsen calls a "vendetta system" (1934, p. 11). If the use of force is admitted with the ex post facto rule there is no explicit limitation for the state which is subject to the intervention to consider that intervention an unlawful act and, in return, exercise its 
right of self-defense against the intervening state, which in its turn would retaliate and so on.

Regarding TIAR and the possibility that this treaty is used to justify humanitarian intervention through R2P to deal with the contemporary crisis in Venezuela, some commentary is fitting. Created during the Cold War, the treaty adopts a "hemispheric defense doctrine", i.e., an attack against one of the member states is an act of aggression against all of the parties of the pact and, consequently, every state is lawfully entitled to act in self-defense (Article 3.1). Menezes argues that the document is inspired by the "Blum Doctrine" of solidarity among the American peoples, which, in turn, fundaments the common defense of the American continent against internal or foreign enemies (MENEZES, 2010, p. 149-150). The treaty was called upon by Argentina during the Malvinas (Falklands) conflict between the LatinAmerican state and the United Kingdom. However, the United States of America sided with its Northern Atlantic ally. After the 9/11 attacks, Brazil evoked TIAR instead of signing bilateral treaties with the USA (some commentators justify the Brazilian decision on the well-known ineffectiveness of the treaty). Nevertheless, alongside other states, Mexico denounced TIAR in 2002 (ceasing to be in force concerning Mexico as of 2004) because the Americas did not have external threats that justified the treaty and, on the other hand, the internal instabilities suffered by the states were outside TIAR's vocation (SENNES; ONUKI; OLIVEIRA, 2006).

On September $11^{\text {th }}, 2019$, through a voting by the states that are still parties to TIAR, a Resolution was passed to establish the Agreement's Organ of Consultation, to convene the Meeting of Ministers of Foreign Affairs, and to inform the UNSC about all activities related to the Venezuelan crisis (OAS, 2019b). It is curious to point out that, through its Interim President Juan Guaidó, Venezuela is among the states favorable to the convocation of TIAR. Nevertheless, under concurrent President Nicolás Maduro, Venezuela's Ministry of Foreign Affairs released a statement in the same day denouncing the invocation of the treaty, stating that it was a "[...] despicable decision of a small group of governments of the region $[\ldots] "$, and pointing out that "[...] Venezuela will continue to adhere to the principles of 
the Charter of the United Nations, respect for international law, the practice of multilateralism and peace diplomacy [...]" (VENEZUELA, 2019). Moreover, the Venezuelan state had denounced TIAR in 2013; however, through Guaidó, it deposited the instruments of ratification of TIAR in August 2019 (OAS, 2019a). ${ }^{9}$

Withal, concerning its legal content, TIAR is not an exception to the rules presented above regarding regional organizations. It mentions that every controversy will first undergo the procedures of the Inter-American System before referring it to the UNGA or the UNSC (Article 2), and, simultaneously, the treaty states that the member states will not resort to the use of force in any manner inconsistent with the provisions of the UN Charter (Article 1 of TIAR). Moreover, while it mentions that measures of self-defense may be taken until the UNSC has taken the procedures it deems necessary (Article 3.4), it also points out that, in conformity with Articles 51 and 54 of the UN Charter, information on the activities undertaken will be immediately sent to the UNSC (Article 5 of TIAR). Hence, from a legal standpoint, TIAR must be interpreted and applied within the framework set by the UN Charter's rules relating to the use of force by regional organizations. That is, the same conclusions regarding these organizations apply to actions under TIAR.

\subsection{THE VETO POWER OF THE PERMANENT MEMBERS OF THE SECURITY COUNCIL}

Moreover, there is an overarching difficulty concerning the raison d'être of R2P. In essence, R2P was created as an answer to the alleged failures of the international community to respond to humanitarian crises adequately. One of the significant deficiencies of timely action is arguably the procedure within the UNSC. This is to be expected given the central duties and responsibilities of the organ to maintain peace and international security and the veto powers of the permanent

\footnotetext{
${ }^{9}$ At the time of the writing of this paper, there are no further relevant developments on the Venezuelan situation and the potential usage of TIAR to justify a humanitarian intervention or any other measure.
} 
members. Hence, it can be argued that R2P is created as an attempt to overcome the inherent complexities of the UNSC procedures and its potential failures.

Following the genealogy of the Holy Alliance created during the Napoleonic Wars, the UN adopts a similar strategy, centralizing the most substantial economic and military forces at its time, it attempts to secure peace by preventing the resurgence of any political uprising capable of threatening the current order. Moreover, by concentrating the forces into one organization, it tries to balance power and, to a certain extent, ensure minimal cooperation between its leaders, attempting to avoid a new conflict. In the center of the UN, the UNSC emerges as a mechanism that aims to provide a stage for dialogue between the victors of the Second World War. In these terms, the UNSC is divided into permanent and non-permanent members. ${ }^{10} \mathrm{~A}$ segregation that challenges legal basis (KELSEN, 1946, p. 1118). Even if during the debates that preceded the formation of the UN the Soviet Union argued that the permanent five would have greater responsibilities when compared to the other participants (UNCIO, 1945, p. 351), these arguments are, at most, of a political nature. Considering the UN Charter as a legal document, there are no greater duties or responsibilities to a permanent member than to any of the other members of the UN (KELSEN, 1946, p. 1117).

Be it as it may, the permanent members are lawfully empowered with what is called the "veto right". The veto instrumentally allows any of the permanent members to halt any decision of the UNSC to be taken, given that the UN Charter requires decisions on procedural matters to be made by a unanimous affirmative vote of the permanent members. However, even non-procedural issues can be vetoed considering that the decision on a definition of what is a procedural or non-procedural matter is a procedural matter in itself and, thus, is subject to veto (double veto) (KELSEN, 1951, p. 239; CONFORTI, 2005, p. 69-71). The inevitable effect of the

10 The permanent members, according to the UN Charter, are the People's Republic of China (formerly the Republic of China), France, the Russian Federation (formerly the Union of Soviet Socialist Republics), the United Kingdom of Great Britain and Northern Ireland, and the United States of America. 
voting procedure conferring the right of veto upon the permanent member is apparent. No decision can be taken against the will of one of these states, even if a permanent member is directly involved in the matter to which the decision refers (KELSEN, 1951, p. 265).

The veto was the cause for many stalemates during the UNSC practice across the years, with its intensity diminishing after the end of the Cold War (DAG HAMMARSKJÖLD LIBRARY, 2017). However, from a legal standpoint, the veto power is still in effect; nothing stops it from being used, including when the Security Council is deciding matters concerning international peace and security (FREDERKING, 2007, p. 28; HURD, 2007, p. 191). Nonetheless, even if there are convincing arguments against it, the veto power is legal, i.e., valid, including the double veto mentioned above, which is recognized in the UN's official repertory of practices (UN, 2016). Hence, from a strictly legal standpoint, there is nothing "wrong" with the use of veto rights by the permanent members of the UNSC. What R2P fails to consider is that a veto imposed or threatened is a sound legal practice under the UN Charter. Thus, if there is such a situation and, nonetheless, the UNGA or a regional organization still decides to carry on the usage of force, they will be disrespecting a valid UNSC decision. If a state is authorized to recommend the use of armed force - although some permanent members of the Council have voted against taking enforcement action measures because they considered that no threat to or breach of the peace existed - in practice, through R2P, that state acts as an "appeal court" to the UNSC. It does not seem that this is an adequate interpretation of the Charter's rules concerning the use of force and veto powers. ${ }^{11}$

There is a considerable difference between a deadlock between the permanent members of the UNSC and the usage of the veto power as an accountable exercise in restraint (WEBB, 2014). Take the failed USA attempts to convince the UNSC on authorizing the recourse to force against Iraq. The USA's officials criticized the procedure, accusing the UN of failing to deal with the matter

${ }^{11}$ Kelsen presents a similar argument while criticizing the "Uniting for Peace" procedure (1951, p. 977). 
properly. Another interpretation is that the system did not fail. Rather, two-thirds of the UNSC concluded that - instead of the use of force - the appropriate measures would be to strengthen the in loco UN inspectors and to position more troops in the borders of Iraq to deter further defiance from Saddam Hussein (TAFT IV, 2003, p. 557-558; FRANCK, 2006, p. 102-13).

\section{BETWEEN UNSC REFORM AND RULE DETERMINACY}

Despite the arguments presented above, it is impossible to ignore the intrinsic complexities and risks that are posed by the UNSC dispute settlement mechanism. An instrument that is legally susceptible to being "blocked" in cases where some of its members disagree will be unable to properly deal with situations of crisis resolving the disputes placed before it. After all, these are the most confrontational instances and, thus, even more susceptible to disagreements that, in turn, could lead to a veto that will prevent the matter of being adequately dealt with. Kelsen spoke about this issue very lucidly:

The inevitable effect of the voting procedure conferring the right of veto upon each of the permanent members must be that no decision of any importance can be taken against the will of one of the privileged states even if this state is involved in the matter to which the decision refers. [...] Consequently, the Security Council sometimes will not be able to exercise its most essential functions, especially those referred to in Article 39. (KELSEN, 1951, p. 265)

The UNSC mechanism is inherently problematic. One may even say that, by requiring the concurrent vote of its permanent members, unanimous agreement is needed and, thus, by itself, the procedure leaves room for an international dispute to remain unresolved. Furthermore, the fact that the veto blocked a solution does not mean that the dispute will not be dealt with in some way; the litigating parties may attempt to resolve this issue by other means that may perhaps be less than legal. In some way, this seems to be the case of R2P. Humanitarian crises are a grave issue, 
and the international legal system based on the UN Charter does not present an adequate solution. Even if humanitarian interventions are a controversial answer to the problem at hand, R2P is an attempt to offer a solution. However, considering the aforementioned, R2P's reasoning is not only debatable, it also seems to contradict the law in effect directly (the UN Charter).

Thomas Franck has a series of investigations on the reasons why nations obey international law. (This theme goes far beyond the limitations of the research, given that it goes outside the legal scope of the analysis at hand. However, for the purposes herein, the author presents a relevant interpretation.) Considering the use of force in Iraq and Kosovo in disagreement with Article 2 of the UN Charter, some argue that states that violate the rights of their people and states that harbor terrorists are no longer entitled to the sovereign rights of territorial integrity (a similar interpretation to the one presented by R2P). These interpreters assert that the UN Charter must be interpreted in a light that corresponds to "the realities of international politics" (SIMPSON, 2004, p. 334). Franck, on the other hand, seems to disagree with this interpretation (FRANCK, 1990). Determinacy, according to Franck, is the literary-structural property of a norm whose content is readily ascertainable (1998, p. 715). The text of Article 2 appears to be transparent enough for its content to be determinant. The use of force under contemporary international law is under a legal monopoly of the UNSC (even self-defense, as seen, is subject to being ratified by the Council's decision). It is evident, however, that the Charter was written and approved under a different political paradigm. Circumstances, priorities, and values change. Substantive and procedural rules must also be adapted. The veto and the threat of a veto is a grave issue that has paralyzed the UNSC in the past and may return to usage, hindering appropriate action. However, "violations of treaties, and of universal treaties in particular, are no substitutes for legitimate amendments" (FRANCK, 2006, p. 93-94).

UNSC reform is vital. Appropriate changes must be made to provide international tools that are appropriate in dealing with the risk of humanitarian crises. An alternate solution to a political mechanism such as the UNSC is, as argued by 
Kelsen, an international court with compulsory jurisdiction (KELSEN, 1944). Conceivably adapting the statutes of the International Court of Justice or the International Criminal Court, or providing a creative interpretation of the law in effect to give them peremptory jurisdiction over these matters through the UNSC, might be an impartial (or at least non-political) alternative. Regardless, what seems to be sure is that at least one aspect of the Charter procedures must not change, be it through reform or reinterpretation of the law in effect. Similar to the argument presented by Franck (2006, p. 105), in a contemporary world of global interdependence, the basic notion that the case for the use of force must be submitted and accepted by a collegiate body, and not the individual state, is a necessity. Adopting an opposite path will relapse the international community into an even more primitive vendetta system. Foxes in charge of the henhouse; states deciding whether their own military dealings are legitimate.

\section{FINAL CONSIDERATIONS}

In this paper, the goal was to study the contemporary just war doctrine of humanitarian intervention through R2P in a strictly legal light, considering the just war doctrine in light of contemporary international law. At this point, this paper concludes that, if there is still a just war doctrine, it would be binary (legal or illegal). It must follow one of the situations contained in the Charter for the use of force to be legally valid. This conception is closely related to the next subject that was analyzed, the general framework for the use of force in the UN Charter. The conclusion is that there is a perceptive legal monopoly on the use of force through the UNSC.

Based on this preliminary set of results, the paper analyzed R2P as a legal concept. (i) The conclusion is that R2P adopts a just war formula that disagrees with the rules set in the UN Charter for the use of force. R2P presents cases of violations of human rights, which it considers that justify the use of force in international relations even if there is no legislative gap in the UN Charter that allows this 
interpretation. (ii) Moreover, R2P ignores that the UN Charter indicates the UNSC as the organ responsible for deciding over the use of force in international relations. In an attempt to interpret the "Uniting for Peace" procedure and rules concerning regional agreements, R2P ignores the legal limitations set in the UN Charter and even jus cogens norms concerning the prohibition on the use of force. (iii) Additionally, R2P can be interpreted as an attempt to overcome what could be considered failures in the UNSC's procedure, particularly the use of veto rights by the permanent members of the organ. Again, the institute ignores that the veto rights are a legal mechanism set in the UN Charter and that by exercising it, the member is, in reality, making use of a valid instrument.

In sum, this research concludes that R2P is a creative project that attempts to offer an interesting interpretation in international law trying to overcome some limitations which it considers undesirable. However, in a strictly legal analysis, R2P has several aspects that are open to questioning and criticism. Moreover, as presented, there are structural elements that are legally unsustainable. In this sense, regardless of political and moral beliefs, it is possible to point out that R2P presents grave legal deficiencies. There are many valuable arguments in favor of and against humanitarian intervention. The same goes for UN and UNSC reform (it is not possible to ignore the inherent complexities caused by the veto rights). Divergent views have the relevance of their own but, in a legal analysis, there is a difference between what is and what ought to be. Regardless of personal and collective beliefs, R2P is a relevant legal institute that has the power to affect world politics and, perhaps, even be recognized as an emerging international norm. However, at the current state, the ICISS proposal ignores fundamental rules of the basic norm of the international community, the UN Charter, and, as a consequence, the use of force through R2P is unlawful. 


\section{REFERENCES}

ANNAN, Kofi A. We The Peoples: The Role of the United Nations in the 21st Century. New York: United Nations, 2000.

BADESCU, Cristina Gabriela. Humanitarian Intervention and the Responsibility to Protect: Security and Human Rights. Oxon: Routledge, 2011.

COURT OF JUSTICE OF THE EUROPEAN UNION. Kadi v. Council and Commission. The judgment of the Court of First Instance (Second Chamber, Extended Composition) 21 September 2005 Case T-315/01. 2005.

DAG HAMMARSKJÖLD LIBRARY. Security Council Veto List in Reverse Chronological Order, 2017-1946. UN Documentation Research Guide, 2017.

DORR, Noel. The Responsibility to Protect: An Emerging Norm?. Irish Studies in International Affairs, Vol. 19, 2008.

EVANS, Gareth. The Responsibility to Protect. Washington: The Brookings Institution, 2008.

FRANCK, Thomas M. Legitimacy in the International System. American Journal of International Law, vol. 82, n. 4, oct. 1988, p. 715. Press, 1990.

The Power of Legitimacy Among Nations. New York: Oxford University

. The Power of Legitimacy and the Legitimacy of Power: International Law in an Age of Power Disequilibrium. American Journal of International Law, vol. 100, n. 1, jan. 2006.

FREDERKING, Brian. The United States and the Security Council: Collective Security Since the Cold War. London: Routledge Taylor \& Francis Group, 2007.

GRANT, John P.; BARKER, J. Craig. Parry \& Grant Encyclopaedic Dictionary of International Law. 3rd ed. New York: Oxford University Press, 2004.

GROSS, Leo. The Peace of Westphalia, 1648-1948. The American Journal of International Law, Vol. 42, No. 1, Jan, 1948.

GROTIUS, Hugo. The Rights of War and Peace - Book II. Edited by Richard Tuck. Indianapolis: Liberty Fund, 2005.

HEHIR, Aidan; MURRAY, Robert. Libya, the Responsibility to Protect and the Future of Humanitarian Intervention. New York: Palgrave Macmillan, 2013. 
HERODOTUS, The Histories Books I and II. Translated by A. D. Godley. Cambridge: Harvard University Press, 1975.

HOMER. The lliad. Translated by Robert Fagles. New York: Penguin Books, 1991.

HORACE. Odes and Epodes. Translated by C. E. Bennett. Cambridge: Harvard University Press, 1995.

HURD, lan. After Anarchy: Legitimacy \& Power in the United Nations Security Council. New Jersey: Princeton University Press, 2007.

ICISS (International Commission on Intervention and State Sovereignty). Supplementary Volume to the Report of the International Commission on Intervention and State Sovereignty. Ottawa: International Development Research Centre, 2001a.

Research Centre, 2001b.

ICJ (International Court of Justice). Application of the Convention on the Prevention and Punishment of the Crime of Genocide. Provisional Measures, Order of 13 September 1993 - Separate Opinion of Judge ad hoc Lauterpacht. ICJ. Reports 1993.

Armed Activities on the Territory of the Congo (Democratic Republic of the Congo v. Uganda). Judgment, ICJ. Reports 2005.

Case Concerning Military and Paramilitary Activities in and against Nicaragua (Nicaragua v United States). ICJ, Merits, Judgment of 27 June 1986.

JOHNSON, Larry D. "Uniting for Peace": Does it Still Serve Any Useful Purpose?. AJIL Unbound, American Society of International Law, Vol. 108, 2014.

KELSEN, Hans. Collective Security and Collective Self-Defense Under the Charter of the United Nations. The American Journal of International Law, vol. 42, n. 4, 1948.

Derecho y Paz en Las Relaciones Internacionales. Translated by Florencio Acosta. México: Fondo de Cultura Económica, 1996.

. Organization and Procedure of the Security Council of the United Nations. Harvard Law Review, vol. 59, 7, 1946. 1944.

. Peace Through Law. Chapel Hill: The University of North Carolina Press, 
. Principles of International Law. New York: Rinehart \& Company, 1952.

. Recent Trends in the Law of the United Nations. Social Research, The New School, vol. 18, n. 2, June 1951.

. The Law of The United Nations. London: Stevens \& Sons Limited, 1951.

. The Legal Process and International Order. The New Commonwealth Research Bureau Publications, series A, n. 1. London: The New Commonwealth, 1934

LIIVOJA, Rain. The Scope of the Supremacy Clause of the United Nations Charter. British Institute of International and Comparative Law. The International and Comparative Law Quarterly, Vol. 57, N. 3, July, 2008.

LINDERFALK, Ulf. Understanding the Jus Cogens Debate: The Pervasive Influence of Legal Positivism and Legal Idealism. In: HEIJER, Maarten den; WILT, Harmen van der (Ed.). Netherlands Yearbook of International Law 2015 - Jus Cogens: Quo Vadis? Hague: Springer, 2016.

MAHDAVI, Motjaba. A Postcolonial Critique of Responsibility to Protect in the Middle East. Perceptions, Vol. XX, n. 1, Spring, 2015.

MARCOS, H.J.B. A Apreciação Judicial dos Atos do Conselho de Segurança pela Corte Internacional de Justiça em uma Perspectiva Kelseniana. Dissertação de Mestrado (Ciências Jurídicas). Universidade Federal da Paraíba Centro de Ciências Jurídicas, João Pessoa, 2018.

MENEZES, Wagner. Derecho Internacional en América Latina. Brasília: FUNAG, 2010. . Tribunais Internacionais. São Paulo: Saraiva, 2013.

ORFORD, Anne. Reading Humanitarian Intervention: Human Rights and the Use of Force in International Law. Cambridge: Cambridge University Press, 2003.

OAS (Organization of American States). B-29: Inter-American Treaty of Reciprocal Assistance (Rio Treaty). Washington, 2019a. Available at: <http://www.oas.org/juridico/english/Sigs/b-29.html>. Accessed on: 19 Sept. 2019.

Permanent Council Resolution 1137 (2245/19), Convocation of the Meeting of the Organs of Consultation of the Inter-American Treaty of Reciprocal Assistance (TIAR). 17 Sept. 2019. Washington, 2019b.

PETERKE, Sven. Manual Prático de Direitos Humanos Internacionais. Brasília: Escola Superior do Ministério Público da União, 2009. 
. Urban Insurgency, 'Drug War' and International Humanitarian War: The Case of Rio de Janeiro. International Humanitarian Legal Studies, 1, 2010.

RAYMOND, Gregory A.; KEGLEY JR., Charles W. Preemption and Preventive War. In: HENSEL, Howard M. (Ed.). The Legitimate Use of Military Force: The Just War Tradition and the Customary Law of Armed Conflict. Hampshire: Ashgate Publishing, 2007.

ROISMAN, Joseph. Greek Perspectives on the Justness and Merits of the Trojan War. College Literature, vol. 35, n. 4, Homer: Analysis \& Influence, John Hopkins University Press, Fall 2008.

SENNES, Ricardo; ONUKI, Janina; OLIVEIRA, Amacio Jorge de. The Brazilian Foreign Policy and the Hemispheric Security. Revista Fuerzas Armadas y Sociedad, vol 1, Santiago, 2006.

SHAW, Malcolm N. International Law. 8. ed. Cambridge: Cambridge University Press, 2017.

SIMPSON, Gerry. Great Powers and Outlaw States: Unequal Sovereigns in the International Legal Order. Cambridge: Cambridge University Press, 2004.

SORTO, Fredys Orlando. A Doutrina Bush das Guerras Preventivas e o Sistema das Nações Unidas. Verba Juris, ano 4, n. 4, 2005.

TAFT IV, William H.; BUCHWALD, Todd F. Preemption, Iraq and International Law. American Journal of International Law, vol. 97, n. 3, jul. 2003.

TOMUSCHAT, Christian. The Lockerbie Case Before the International Court of Justice. Review: The International Commission of Jurists, vol. 48, 1992.

UN (United Nations). Repertory of Practice of United Nations Organs, Chapter V - The Security Council, Article 27. Codification Division Publications, Office of Legal Affairs, 2016.

UNCIO (United Nations Conference on International Organization). Summary Report of Eleventh Meeting of Committee III/1. New York, 1945.

UNGA (United Nations General Assembly). General Assembly 60/1 - 2005 World Summit Outcome. Resolutions Adopted by the General Assembly on 16 Sept. 2005.

. General Assembly 377 - Uniting for Peace. Resolutions Adopted by the General Assembly During its 302nd Plenary Meeting, 1950. 
VENEZUELA. Ministerio del Poder Popular para Relaciones Exteriores. Bolivarian Government Categorically Denounces the Invocation of the Disastrous TIAR. September 11th 2019. Caracas, 2019. Available at: <http://mppre.gob.ve/en/comunicado/government-denounces-disastrous-tiar>. Accessed on: 19 Sept. 2019.

VITORIA, Francisco de. Political Writings of Francisco de Vitoria. Edited by Anthony Pagden and Jeremy Lawrance. Cambridge: Cambridge University Press, 2010.

WEBB, Philippa. Deadlock or Restraint? The Security Council Veto and Use of Force in Syria. Journal of Conflict \& Security Law, vol. 19, n. 3, 2014.

WEISS, Thomas G. Overcoming the Security Council Reform Impasse: The Implausible versus the Plausible. Dialogue on Globalization, Occasional Papers, n. 14, New York: Friedrich-Ebert-Stiftung, 2005.

ZOLO, Danilo. Hans Kelsen: International Peace Through International Law. European Journal of International Law, Vol. 9, 1998. 